\title{
Educating Archivists: Speculations on the Past, Present, and Future
}

\author{
Richard J. Cox \\ New York State Archives and Records Administration, Cultural Education Center, Albany, New York 12230
}

\begin{abstract}
This article examines historical and present issues and future prospects for archival education. Most important recent developments include the emergence of new graduate level programs and the Society of American Archivists' adoption of new guidelines for these programs and for individual certification. Future prospects depend on the resolution of several issues which concern recruitment, distinguishing educational requirements for areas of archival specialization, clarification of the role of the practicum in the educational process, and the definition of the archivist's role in the information society. It appears, in light of the above, that the archival profession and its education face a brighter future than ever before.
\end{abstract}

\section{The Background of Archival Education}

Only a decade ago, archival education was described as a "field in flux," [1] in a "medieval state," [2] "unfinished business," [3] and in its "infancy, at best in adolescence" [4]. These descriptions were not comforting to members of a profession formally organized for nearly half a century. The proper education for an archivist has been an issue for even longer than that. The earliest and most prevalent debate concerned whether archivists should be trained in history or in library schools [5]. Other debates have stemmed from how to develop adequate archival educational programs when most archival educators and practitioners acknowledge that archival administration is "compounded of parts of many other sciences or fields of knowledge, together with certain principles and techniques derived from practical experience" [6].

With the profession's rapid growth from the late 1960s to the early 1980 s, resulting primarily from institutions' growing interest in establishing programs to care for their historical records, a new desire to formalize the content of archival education developed. The Society of American Archivists (SAA) adopted its first graduate education guidelines in 1977, debated the certification of individual archivists, and started a continuing education program. More recently SAA adopted considerably expanded graduate archival education guidelines [7]. Some new graduate programs have been formed, for example, the first fully independent graduate program in North America [8], and prospects seem excellent that five or six other strong programs may emerge by the early 1990s [9]. There has also been an expansion in the scope and quality of archival literature necessary to support the improvement of archival education. This has been matched by an intensive selfanalysis of and planning for the archival profession with a major focus on archival credentials and training, new discussion about and commitment to an individual certification program, and increasing interest in midcareer and advanced continuing education. Great needs certainly remain for strengthening archival education [10], but its future seems brighter than ever before.

\section{The Present State of Archival Education}

A near consensus about educational content for archivists exists in the profession today. Prospective archivists need a firm understanding of the nature of information, records, and historical documentation; history and the continuing role of archives in modern society; basic archival functions such as appraisal and acquisitions, arrangement and description, preservation management, reference and access, and advocacy and outreach; the legal and ethical implications of records administration; cooperative ventures like automated descriptive networks and documentation strategies; and basic management principles such as organizational theory and practice, program planning, human resources management, and resource development [11].

Central to the present notion about archival education is a stronger conviction that archivists have their own specialized knowledge, even if it still requires formal definition and description. Although archival training must include courses in related fields - historical methodology, public or applied history, information science, conservation, business and public administration, records management, historical editing, and oral history-historical records administration has its own theoretical foundation and fundamental principles [12]. 
A concomitant trend with developments in graduate archival education has been the strengthening of continuing archival education, both basic and advanced. The SAA recently established an Education Office, with its first full-time Education Officer, to develop short courses in "archival fundamentals," a hallmark of SAA's work since the mid-1970s, and "advanced archival training," especially oriented to mid-career archivists. SAA is preparing a comprehensive plan for archival education that relates basic institutes and workshops to graduate education and advanced training and the archival profession's needs. Related professional associations, such as the National Association of Government Archives and Records Administrators (NAGARA) and the New England Archivists (NEA), have taken similar steps. Other ambitious efforts hy additional professional associations will likely emerge in the next few years.

\section{Continuing Issues in Archival Education}

Despite a ncw vitality in their education, archivists still face a number of important issues. All remain important concerns since education and training provide the distinguishing quality for the professional corps of archivists that manage this country's historical records. These issues are as follows:

\section{Regulation of the Quality of Archival Educational Programs}

The new SAA graduate guidelines only "guide" archival educators. SAA, with allied professional associations like the American Library Association, needs to consider accreditation of graduate archival programs and other possible methods to ensure the continuing quality of archival training. Communicating more effectively to other disciplines that seek a role in educating archivists about the required knowledge and training of prospective archivists, such as public history [13] and library science, is equally as important.

\section{The Impact of Individual Certification on Archival Education}

There are sharply opposing views about the value of certification for archival education and the profession, some arguing it will weaken the continuing development of formal graduate education and others contending that it will strengthen all forms of archival education [14]. Certification can strengthen the educational preparation of prospective archivists, if it is not viewed as a replacement for education but as another means by which to ensure the competency of practicing archivists. Certification can result in the more precise definition of archival work and professional standards, improvement of archival literature, and a higher public profile of archival administration.
Distinguishing Educational Requirements for Levels of Archival Specialization

At present, there is little distinction made in archival education for individuals who work as paraprofessionals, technicians and specialists, or as administrators [15]. The archival profession must consider the differing needs of such individuals and direct them to appropriate existing training courses and programs or create the courses and programs needed. Archivists also need better definition of the necessary qualifications and duties of these various positions.

\section{The Place of the Practicum in Archival Education}

A fundamental aspect of archival education has been the practicum, an opportunity for the student to obtain first-hand experience in an archival repository. Although the SAA adopted guidelines for the practicum in 1980 [16], there has been virtually no evaluation of the benefits of this component of archival education [17]. Some argue that the practicum has extremely limited value because of its traditional emphasis only on archival processing, giving the impression that archival work is more craft than profession and minimizing the importance of archival theory. If the practicum is to have a place in the future graduate education of archivists, then it must be expanded to encompass many archival tasks.

\section{Archival Research and Development and Education}

With a few exceptions, there is little in the archival profession resembling organized research and development. At least one archival commentator has argued forcefully for the need for graduate archival education programs to fill this need [18]. These programs must urge their students to conduct serious research in important archival subjects, and must provide archival educators the time and resources necessary for research and writing on the theory and practice of the field.

\section{Attracting Qualified Individuals to Become Archivists}

Although there appears to be a lack of sufficiently qualified candidates for archival positions at entry, intermediate, and upper level positions, there are now no formal efforts to recruit undergraduate students to consider careers in archival administration. Individuals generally learn about archival careers at the graduate level and then only by happenstance. This problem is further compounded by a continuing weak public image of the archival profession. Archivists must communicate to undergraduate students, in all fields, the nature, opportunities, and importance of archival careers.

\section{Continuing Role of the Archival Profession in the Modern Information Society}

Here, archivists face the same challenges as librarians, data processors, management information systems person- 
nel, and other groups concerned with society's information needs and uses. Will there be one information profession that includes all of these now related "information" fields, or will they simply have similar educational programs and professional agendas? One information profession will likely emerge, because of the rapidly converging automated information systems [19]. Archivists must maintain, however, their distinctive mission - the identification, selection, preservation, and management of information of enduring value - since they are the main information profession with this responsibility. Individuals training to be archivists in the future will have more exposure to IRM, records management, and other library and information science courses. These related fields must also gain an increased awareness from archivists about the preservation of information with continuing value to information creators, users, and society.

\section{Conclusion: Prospects for the Future of Archival Education}

Looking into the future is at best chancy, although the prospects for archival education seem very good. Although the archival profession will always be small when compared to its relations including librarianship, this profession will show steady growth in the coming decades. There are increasing demands for archival skills and perspective in government, business, and other informationintensive areas. This is not due to any growing public historical consciousness, but because of the archivists' expertise in the selection and management of information with enduring value.

What does all this mean? By the early 1990s, there may be at least a half-dozen multi-course graduate programs in archival administration, located in history, public, or applied history, and information/library science programs, each having their own unique and valuable focus. These programs will annually prepare from 50 to 100 archivists qualified to fill specialist or administrative posts. At the same time, continuing education programs will be flourishing at both basic and advanced levels. The basic courses will be providing introduction to individuals training for archival para-professional or support positions or to other professionals seeking introduction to archival administrative principles and practices. The advanced courses will eventually constitute a well-rounded program for archivists in mid-carcer. As a result of this activity, the archival profession's literature, image, and practice will be stronger than ever and society's documentary heritage will be better protected.

\section{References}

1. Bower, A. S. "Whence and Whither: A Survey of Archival Education." Georgia Archive. 5(1):54-55; 1977.
2. Geary, J. W. "A Fading Relationship: Library Schools and Preappointment Archival Education Since 1973." Journal of Education for Librarianship. 20(1):26; 1979.

3. Mason, P. P. "Archival Education: The Need for Standards." In: Fyfe, J.; Collier, C., Eds. Symposium on Archival Education School of Library and Information Science University of Western Ontario Saturday, July 28th, 1979. London, Ontario: School of Library and Information Science, University of Western Ontario: 1980: 67.

4. McCrank, L. J. "Prospects for Integrating Historical and Information Studies in Archival Education." American Archivist 42(4):443; 1979.

5. Goggin, J. "That We Shall Truly Deserve the Title of 'Profession': The Training and Education of Archivists, 1930-1960." American Archivist. 47(3):243-54; 1984; and Berner, R. C. "Archival Education and Training in the United States, 1937 to Present." Journal of Education for Librarianship. 22(1):3-19; 1981.

6. Buck, S. J. "The Training of American Archivists." American Archivist. 4(2):85; 1941.

7. SAA Newsletter, May 1987, pp. 10-12.

8. Eastwood, T. "The Origins and Aims of the Master of Archival Studies Programme at the University of British Columbia." Archivaria. 16:35-52; 1983.

9. Programs that have great promise include the combined MA/MLS program at the University of Maryland; University of Western Washington; University of Massachusetts at Boston; University of Texas at Austin; and the School of Information Science and Policy at the State Universily of New York at Albany.

10. Planning for the Archival Profession: A Report of the SAA Task Force on Goals and Priorities. Chicago, IL: Society of American Archivists: 1986: 14-15.

11. This description conforms to the new SAA graduate archival education guidelines, which the author was involved in drafting.

12. Burke, F. G. "The Future Course of Archival Theory in the United States." American Archivist. 44(1):40-46; 1981.

13. This is especially important for the rapidly emerging public history field. See Cox, R. J. "Archivists and Public Historians in the United States." Public Historian. 8(3):29-45; 1986.

14. A description of the present certification plan is in the SAA Newsletter, August 1986. pp. 6-9. For the author's views on how certification and educations fit into the prospects for the archival profession, see "Professionalism and Archivists in the United States," American Archivist. 50(1):229-47; 1986.

15. European archival educators have emphasized such levels; see Cook, M. "An International Standard for the Training of Archivists and Records Managers." UNESCO Journal of Information Science, Librarianship and Archives Administration. 4(2):116; 1982.

16. "Program Standard for Archival Education: The Practicum." American Archivist. 43(3):420-422; 1980.

17. Virtually the only article about this aspect of archival education is LeFurgy, W. G. "The Practicum: A Repository View." American Archivist. 44(2):153-155; 1981.

18. Burke, "Future Course."

19. Warner, R. M. "Librarians and Archivists: Organizational Agenda for the Futurc." Journal of Library Administration. 7(2/3):167-76; 1986.

\section{Suggestions for Further Reading}

Berner, R.C. "Archival Education and Training in the United States, 1937 to Present." Journal of Education for Librarianship. 22(1):3-19; 1981.

Cook, M. "An International Standard for the Training of Archivists and Records Managers." UNESCO Journal of Information Science, Librarianship and Archives Administration. 4(2):114-22; 1982.

Eastwood, T. "The Origins and Aims of the Master of Archival Studies Programme at the University of British Columbia." Archivaria. 16:35-52; 1983. 
Goggin, J. "That We Shall Truly Deserve the Title of 'Profession': The Training and Education of Archivists, 1930-1960." American Archivist. 47(3):243-54; 1984.

McCrank, L. S. "Prospects for Integrating Historical and Information Studies in Archival Education." American Archivist. 42(4):443-55; 1979.
Stielow, F. J. "Continuing Education and Information Management: Or, the Monk's Dilemma." Provenance. 3(1):13-22; 1985.

Warner, R. M. "Librarians and Archivists: Organizational Agenda for the Future." Journal of Library Administration. 7(2/3):167-76; 1986. 